\title{
QUANTITATIVE PHASE ANALYSIS BY X-RAY DIFFRACTION - SIMPLE ROUTES
}

\author{
Stanko Popović \\ Croatian Academy of Sciences and Arts, Croatia \\ Physics Department, Faculty of Science, University of Zagreb, Croatia \\ spopovic@phy.hr
}

\begin{abstract}
The elemental composition of a multiphase material can be obtained by means of chemical and spectroscopic techniques. However, these techniques face a great difficulty in distinguishing the chemical identity of the phases present in the material and in derivation of the fractions of particular phases. X-ray powder diffraction seems to be an ideal technique for the analysis of a multiphase material. Each crystalline phase of the material gives its characteristic diffraction pattern independently of the other phases; this fact makes it possible to identify the phase of interest and to determine its fraction. The intensities of diffraction lines of a given phase are proportional to its fraction and an appropriate quantitative analysis can be performed after the application of the correction for the absorption of X-rays in the material.

The principles of quantitative X-ray diffraction phase analysis of a multiphase material are presented, with a special attention paid to the doping methods. The following methods are described: $(i)$ determination of the fraction of a phase using repeated dopings, (ii) determination of the fraction of a phase using a single doping, (iii) simultaneous determination of the fractions of several phases using a single doping; (iv) determination of the fraction of the dominant phase. The applicability of the doping methods is stated and the optimum conditions to minimize systematic errors are discussed. Recent approaches in quantitative X-ray diffraction phase analysis are also mentioned in short.
\end{abstract}

Keywords: X-ray powder diffraction; quantitative phase analysis; doping methods

\section{КВАНТИТАТИВНА ФАЗНА АНАЛИЗА СО ПОМОШ НА РЕНДГЕНСКА ДИФРАКЦИЈА - ЕДНОСТАВНИ ПАТИШТА}

Хемискиот состав на мултифазен материјал може да се определи со помош на хемиски и спектроскопски техники. Меѓутоа, при користење на овие техники се појавуваат големи тешкотии на патот на дефинирање на хемискиот идентитет на присутните фази во материјалот, како и при определувањето на фракциите на одредените фази. Рендгенската дифракција на спрашени обрасци е една од идеалните техники за анализа на мултифазни материјали. Секоја од кристалните фази во материјалот дава нејзини карактеристични дифракциони максимуми, независно од другите фази. Тоа овозможува да се определат присутните фази, како и нивните фракции. Интензитетите на дифракционите линии на определена фаза се пропорционални со нејзината фракција, што овозможува да се направи квантитативна анализа по примена на корекција на апсорпцијата на рендгенските зраци во материјалот.

Презентирани се принципите на квантитативната фазна анализа на мултифазен материјал со помош на рендгенска дифракција, при што посебно внимание е обрнато на методот на додатоци. Опишани се следните методи: (i) определување на фазна фракција користејќи повторени додавања, (ii) определување на фазна фракција користејќи едно додавање, (iii) симултано определување на фазни фракции користејќи едно додавање и $(i v)$ определување на фракција на доминантната фаза. Наведена е применливоста на методот на додатоци и дискутирани се оптималните услови за минимизирање на систематските грешки. Накратко е наведен и неодамнешниот развој на квантитативната фазна анализа со помош на рендгенска дифракција.

Клучни зборови: рендгенска дифракција на спрашени обрасци; квантитативна фазна анализа; метод на додатоци

\footnotetext{
- Dedicated to Academician Gligor Jovanovski on the occasion of his $70^{\text {th }}$ birthday.
} 


\section{INTRODUCTION}

Quantitative phase analysis of a multiphase system on the basis of its diffraction pattern has been a subject of interest from the very beginning of X-ray diffraction. All simple methods for identification of particular phases in the system and determination of their fractions are based on the principles postulated by Alexander \& Klug [1] and Klug \& Alexander [2]. Let a system consist of several phases denoted with capital letters and let the same notation represent their (mass, weight, molar) fractions, i.e.

$$
A+B+C+\cdots+X+Y+\cdots=1 .
$$

The integrated intensity of a selected diffraction line of a phase, say $A$, is related to its fraction:

$$
I_{A}=K_{A} A /\left(d_{A} \mu\right),
$$

where $d_{A}$ is the density of the phase $A, \mu$ is the mass absorption coefficient of the system, and $K_{A}$ is a factor depending on the nature of the phase $A$, on the selected diffraction line and the geometry of the diffractometer. For pure phase $A$, since $A=1$, (2) changes into

$$
I_{A 0}=K_{A} /\left(d_{A} \mu_{A}\right),
$$

where $\mu_{A}$ is the mass absorption coefficient of the phase $A$. From (2) and (3) it follows:

$$
I_{A} / I_{A 0}=A\left(\mu_{A} / \mu\right) .
$$

The absorption coefficients are not known accurately. Therefore, it is obvious from (4) that the fraction $A$ cannot be obtained simply by measuring the ratio $I_{A} / I_{A 0}$, i.e. by a direct comparison of the diffraction pattern of the system containing the phase $A$ with the pattern of pure phase $A$.

Analogously to (4), for another phase, say $B$, it follows:

$$
I_{B} / I_{B 0}=B\left(\mu_{B} / \mu\right)
$$

From (4) and (5) one obtains

$$
A / B=K_{A B}\left(I_{A} / I_{B}\right),
$$

where

$$
K_{A B}=\left(\mu_{B} / \mu_{A}\right)\left(I_{B 0} / I_{A 0}\right) .
$$

$K_{A B}$ is a constant for the two phases which are considered (in this case $A$ and $B$ ), for the selected diffraction lines and for the diffractometer which is used.
A direct application of (6) is not straightforward, since the absorption coefficients are not accurately known. In order to circumvent this problem, semi-empirical internal standard methods may be used. For each phase, say $A$, the fraction of which is to be determined, a calibration curve is constructed in such a way as to relate $A / S v s . I_{A} / I_{S}$, where $S$ denotes the internal standard. According to (6), the calibration curve is a straight line having the slope $K_{A S}$. The slope is obtained from the intensity measurement of a series of mixtures with known ratios $A / S$. In order to find the fraction of the phase $A$ in the system, a known fraction of the standard $S$ is added to the system, the intensity ratio $I_{A} / I_{S}$ is measured and $A$ is found from the previously constructed calibration curve. More details on the internal standard method, as applied in special cases, can be found in the textbook of Klug \& Alexander [2].

In the method developed by Chung $[3,4]$ no calibration curve is needed, as the absorption coefficients are flushed out of the intensity-fraction equation. The method is based on a previous knowledge, or measurement, of relative (reference) intensities of (the strongest) diffraction lines for each pair of phases that are present in the system, or rather for each phase and a reference phase (corundum, $\alpha-\mathrm{Al}_{2} \mathrm{O}_{3}$ ). All information related to the quantitative composition of the system can be decoded directly from its diffraction pattern.

\section{THE DOPING METHODS}

The doping methods involve the addition, to the original system, of known amount(s) of the phase(s), the fraction of which is (are) to be determined. The corresponding equations, deduced with no approximation, relate the fraction of the phase to be determined to the intensities diffracted by that phase and by any non-added phase which is present in the system, before and after doping. The intensity-fraction equations are free of the absorption coefficients. The methods can be applied to a system containing unidentified phase(s), in simultaneous analysis only for the phases of interest, and in determination of the fraction of the amorphous content. Four doping methods are described in the following sections.

\section{(i) Determination of the fraction of a phase using repeated dopings}

Copeland \& Bragg [5] suggested that the system can be doped with known amounts of the phase, say $A$, the fraction of which is to be determined. The system already contains another phase, 
say $B$, which is considered as the reference phase. The fraction $A^{\prime}$ of the phase $A$ is added to the system. The fraction of this phase in the doped system is now $\left(A+A^{\prime}\right) /\left(1+A^{\prime}\right)$ and the fraction of the reference phase is $B /\left(1+A^{\prime}\right)$. In this case, it follows from (6):

$$
\begin{gathered}
K_{A B}\left(I_{A} / I_{B}\right)^{\prime}=\left(A+A^{\prime}\right) / B, \\
\text { or, } \quad\left(I_{A} / I_{B}\right)^{\prime}=(\text { constant })\left(A+A^{\prime}\right),
\end{gathered}
$$

the prime indicating the intensities measured after doping. The plot of $\left(I_{A} / I_{B}\right)^{\prime}$ as a function of $A^{\prime}$ is a straight line; the fraction sought, $A$, is the absolute value of the $A^{\prime}$-axis intercept. In order to increase the accuracy, several pairs of diffraction lines of $A$ and $B$ can be used.

\section{(ii) Determination of the fraction of a phase using a single doping}

In order to avoid several consecutive dopings, Bezjak \& Jelenić [6] have shown that the fraction of any phase, say $A$, can be determined using a single doping and from only two diffraction patterns. Namely, from (6) and (7) it follows:

$$
\left(I_{A} / I_{B}\right)^{\prime}=\left[\left(A+A^{\prime}\right) / A\right]\left(I_{A} / I_{B}\right) .
$$

The equation (8) relates the intensities of diffraction lines of the sample doped with a known fraction, $A^{\prime}$, of the phase of interest, and the intensities of diffraction lines of the original sample. $B$ is any other phase already present in the system. That is a straight line, and its slope, $\left(A+A^{\prime}\right) / A$, determined from experimental data for all possible intensity ratios, yields the initial fraction of the phase $A$.

\section{(iii) Simultaneous determination of the fractions of several phases using a single doping}

It has been shown by Popovic et al. that the fractions of several phases can be simultaneously determined from only two diffraction patterns: the pattern of the original sample and the pattern of the sample doped with known fractions of all phases of interest $[7,8,9]$. The two patterns are to be taken under the same experimental conditions. In principle, the fractions of all phases in the system can be determined, if known fractions of all phases except one are added. The equations shown below are obtained using the relation that the sum of all fractions after doping also equals 1 , instead of $1+A^{\prime}$, as in the methods $(i)$ and (ii). The method is described for a binary system, for a ternary system with one phase or two phases added, and for a general multiphase system.

\section{Binary system}

Original sample [equations (1) and (6)]:

$$
\begin{gathered}
A+B=1, \\
A / B=K_{A B}\left(I_{A} / I_{B}\right) .
\end{gathered}
$$

If one wants to determine the fraction of the phase $B$, a known fraction of that phase, $B_{a}$, is added to the original sample. Then $A$ is used as the reference phase.

Doped sample:

$$
\begin{gathered}
A_{d}+B_{d}+B_{a}=1, \\
A_{d} /\left(B_{d}+B_{a}\right)=K_{A B}\left(I_{A d} d I_{B d+a}\right) .
\end{gathered}
$$

$A_{d}$ and $B_{d}+B_{a}$ are the fractions of the phases in the doped sample, and $I_{A d}$ and $I_{B d+a}$ are the corresponding intensities. The following is also valid:

$$
A_{d} / B_{d}=A / B .
$$

There are five equations $(9,6,10-12)$ for five unknowns, $A, B, A_{d}, B_{d}$ and $K_{A B}$. It follows that the fractions of the phases are:

$$
B=B_{a} R_{A B} /\left(P-P R_{A B}\right), \quad A=1-B,
$$

where

$$
R_{A B}=\left(I_{A d} / I_{B d+a}\right)\left(I_{B} / I_{A}\right), P=1-B_{a} .
$$

$P$ is the parameter which equals 1 - the fraction of the added phase in the doped sample, or, the fraction of the original composition in the doped sample. An example of the method is shown in Figure 1.

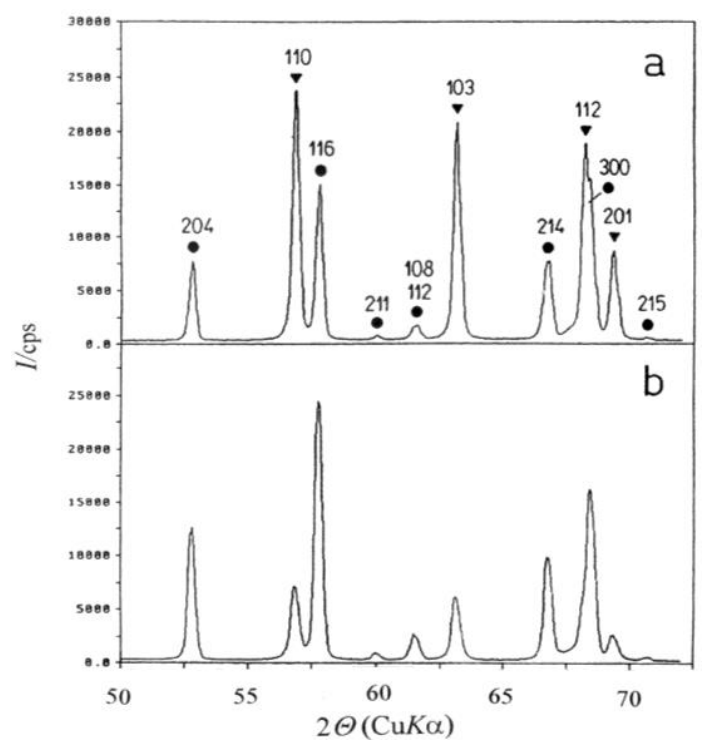

Fig. 1. X-ray diffraction patterns of the system $\mathrm{ZnO}$ $(A=0.5, \boldsymbol{\nabla})+\alpha-\mathrm{Al}_{2} \mathrm{O}_{3}(B=0.5, \bullet)$ : (a) original sample, (b) the sample doped with $B_{a}=0.667$. Radiation $\mathrm{CuK \alpha}$. [12] 


\section{Ternary system} found.

(a) The fraction of one phase, say $B$, is to be

Original sample: In addition to (6) one has:

$$
\begin{gathered}
A+B+C=1, \\
C / B=K_{C B}\left(I_{C} / I_{B}\right) .
\end{gathered}
$$

A known fraction, $B_{a}$, of the phase $B$ is added to the original sample. Then, either $A$ or $C$ may be used as the reference phase.

Doped sample: Besides (11) and (12), the following is valid:

$$
\begin{gathered}
A_{d}+B_{d}+B_{a}+C_{d}=1, \\
C_{d}\left(B_{d}+B_{a}\right)=K_{C B}\left(I_{C d} / I_{B d+a}\right), \\
C_{d} / B_{d}=C / B .
\end{gathered}
$$

It can be shown that, out of eight equations $(15,6,16,17,11,18,12,19)$, there are only seven independent equations for eight unknowns, $A, B$, $C, A_{d}, B_{d}, C_{d}, K_{A B}$ and $K_{C B}$. This means that only the fraction of the added phase, $B$, can be determined. If $B$ is related to either $A$ or $C$, as the reference phase, it follows that there are five equations for five unknowns. The problem can be, therefore, treated in terms of a binary system. If $B$ is related to $A$, one obtains that $B$ is given by (13), with $R_{A B}$ defined by (14). If $B$ is related to $C$, it follows:

$$
B=B_{a} R_{C B}\left(P-P R_{C B}\right), \quad R_{C B}=\left(I_{C d} / I_{B d+a}\right)\left(I_{B} / I_{C}\right) .
$$

In both cases $P=1-B_{a}$. It is obvious that $R_{A B}=R_{C B}$.

(b) The fractions of all three phases are to be found. In this case, known fractions of two phases, say, $B$ and $C$, are added to the original sample. Then $A$ is used as the reference phase. one has

Original sample: In addition to (15) and (6)

$$
A / C=K_{A C}\left(I_{A} / I_{C}\right) .
$$

Doped sample: The fractions $B_{a}$ and $C_{a}$ are added to the original sample. Besides (11) and (12) the following is valid:

$$
\begin{gathered}
A_{d}+B_{d}+B_{a}+C_{d}+C_{a}=1, \\
A_{d} d\left(C_{d}+C_{a}\right)=K_{A C}\left(I_{A d} / I_{C d+a}\right), \\
A_{d} / C_{d}=A / C .
\end{gathered}
$$

There are eight independent equations $(15,6$, $20,21,11,22,12,23)$ for eight unknowns, $A, B, C$,
$A_{d}, B_{d}, C_{d}, K_{A B}$ and $K_{A C}$. It can be shown that in this case the fractions of the phases are given as follows:

$$
\begin{gathered}
B=B_{a} R_{A B}\left(P-P R_{A B}\right), \quad C=C_{a} R_{A C}\left(P-P R_{A C}\right), \\
A=1-(B+C) .
\end{gathered}
$$

The parameter $P$ equals, as previously, the fraction of the original composition in the doped sample,

$$
P=1-\left(B_{a}+C_{a}\right),
$$

while $R_{A B}$ and $R_{A C}$ contain intensities of the added phases, $B$ and $C$, and the intensities of the nonadded phase, $A$, before and after doping:

$$
R_{A B}=\left(I_{A d} / I_{B d+a}\right)\left(I_{B} / I_{A}\right), R_{A C}=\left(I_{A d} / I_{C d+a}\right)\left(I_{C} / I_{A}\right) .
$$

\section{Multiphase system}

The essential points of the doping method can be summarized as follows. Let the system consist of $N$ phases. Its diffraction pattern is taken and a partial or complete identification of the phases is performed. The prominent, non-overlapping (in principle the strongest) diffraction lines of particular phases are chosen and their net integrated intensities are measured. Then the system is doped by known fractions of $M$ phases, the original fractions of which are to be determined $(M=1,2,3, \ldots N-1)$. The intensities of the chosen diffraction lines are measured again. In principle, if $N-1$ phases are added, the original fractions of all $N$ phases can be found. The fraction of any phase, say $X$, in the original sample is given by equation

$$
X=X_{a} R_{Y X} /\left(P-P R_{Y X}\right) .
$$

Here $X_{a}$ is the fraction of the added phase $X$ in the doped sample, and $Y$ is any non-added (reference) phase. $P$ equals the fraction of the original composition in the doped sample, or, 1 - the total fraction of all the added phases in the doped sample. $R_{Y X}$ is expressed through the intensities of the phases $X$ and $Y$ before $\left(I_{X}, I_{Y}\right)$ and after $\left(I_{X d+a}, I_{Y d}\right)$ doping:

$$
R_{Y X}=\left(I_{Y d} / I_{X d+a}\right)\left(I_{X} / I_{Y}\right) .
$$

An example of the method is shown in Figure 2.

One can utilize several pairs of diffraction lines of the phases $X$ and $Y$ in order to increase the accuracy of the measurement. Namely, from (24) and (25) it follows:

$$
I_{X d+a} / I_{Y d}=K\left(I_{X} / I_{Y}\right) .
$$


a)
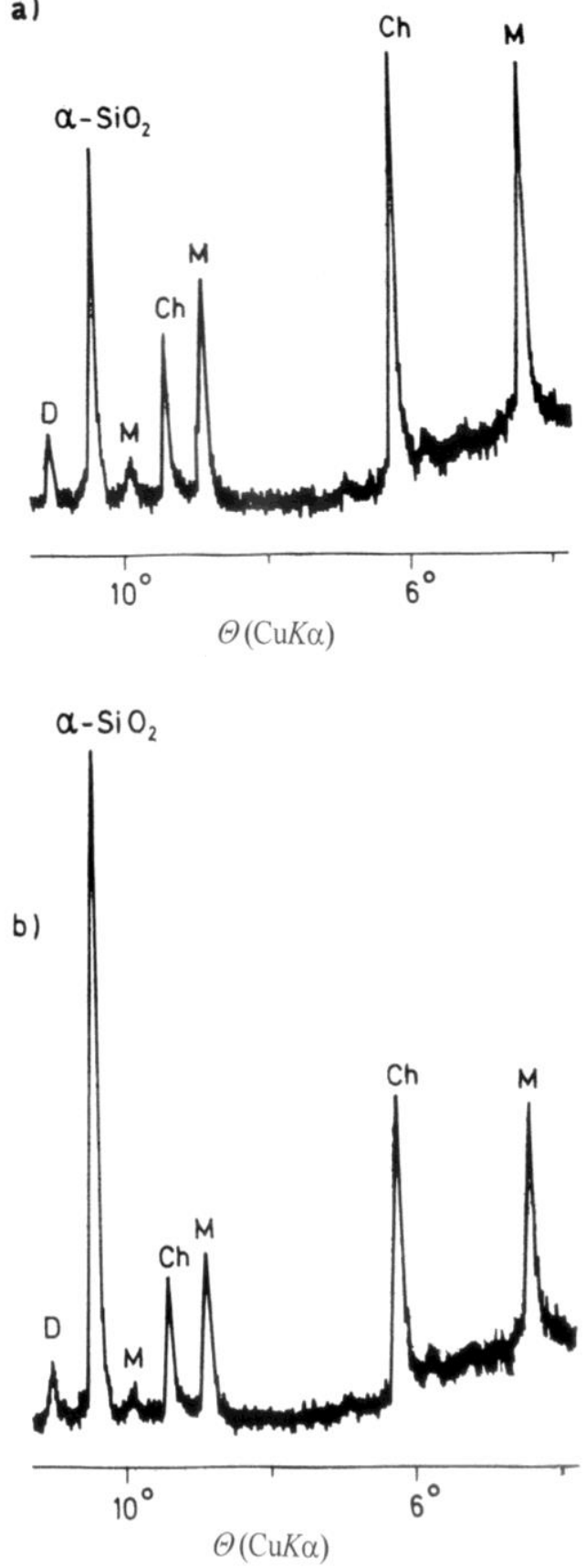

Fig. 2. X-ray diffraction patterns of industrial dust, method (iii), determination of the fraction of quartz, $\alpha-\mathrm{SiO}_{2}(X)$ :

(a) original sample, (b) the sample doped with $X_{a}=0.286$.

The fraction of quartz in the original sample: $X=0.200(10)$. Other phases: $\mathrm{Ch}$, chlorites; $\mathrm{D}$, dolomite; $\mathrm{M}$, micas. Radiation $\mathrm{CuK \alpha}$. [9]

A plot of $I_{X d+a} / I_{Y d}$ as a function of $\left(I_{X} / I_{Y}\right)$ is a straight line with the slope

$$
K=\left(X P+X_{a}\right) /(X P),
$$

from which it follows that the fraction of the phase of interest is given by

$$
X=X_{a} /(P K-P) .
$$

\section{(iv) Determination of the fraction} of the dominant phase

A specific case of the doping method is proposed in which the fraction of the dominant crystalline phase in a multiphase system can be determined by measurement of diffraction line intensities of only that phase $[8,9]$. Let the system contain a phase, say $X$, which is dominant, and let diffraction lines of other phases be weak. The doping method (iii) may not be appropriate in such a case, as diffraction lines of the phase used as the reference phase will be even weaker after doping. In this case, the following procedure may be applied. The diffraction pattern of the original sample is taken $\left(1^{\text {st }}\right.$ pattern $)$ and the intensity of a prominent non-overlapping (in principle the strongest) diffraction line of the phase $X$ is measured $\left(I_{X}\right)$. Then the sample is doped by a known fraction, $X_{a}$, of the phase $X$. The diffraction pattern of the doped sample is taken $\left(2^{\text {nd }}\right.$ pattern $)$, and the intensity of the chosen diffraction line of the phase $X$ is measured again $\left(I_{X d+a}\right)$. Finally, the diffraction pattern of the pure phase $X$ is taken ( $3^{\text {rd }}$ pattern) and the intensity of the same diffraction line is measured once more $\left(I_{X 0}\right)$. It is important that all three diffraction patterns are taken under the same conditions. The fraction of the phase $X$ in the original sample is given by equation

$$
X=\left(X_{a} / P\right)\left(R_{1} / R_{2}\right),
$$

where

$$
R_{1}=1-\left(I_{X d+a} / I_{X 0}\right), \quad R_{2}=\left(I_{X d+a} / I_{X}\right)-1,
$$

and $P$ is the fraction of the original composition in the doped sample,

$$
P=A_{d}+B_{d}+C_{d}+\cdots+X_{d}+Y_{d}+\cdots=1-X_{a} .
$$

Several diffraction lines of the phase $X$ can be used in order to increase the accuracy. However, this method is not applicable in a case where $X$ is close to 1 , as $R_{1}$ and $R_{2}$ then tend to zero and the value obtained for $X$ may not be reliable.

\section{COMMENTS}

The analysis of the described methods (iii) and (iv) shows that it is advisable to choose $X_{a}$ close to 0.5 in order to achieve a better accuracy of $X[8,9]$. Extensive grinding and mixing of the original and doped samples are necessary to ensure sample homogeneity. In case the grains/crystallites are rather small, having the size of, say, 1 to 10 $\mu \mathrm{m}$, the primary extinction is also small. The inte- 
grated intensities of diffraction lines should be precisely measured; the background line may be estimated by application of the appropriate procedures. The pure phase added to the original sample should have a similar degree of crystal perfection as the same phase present in the original sample.

The preferred orientation of the grains/crystallites has to be avoided. In case of its presence, the measured intensities of diffraction lines deviate from the true values corresponding to the random orientation of grains/crystallites. The presence of the preferred orientation can be noticed if rather different values of the fraction of $X$ are obtained for different combinations of diffraction lines of $X$ and $Y$. Grains/crystallites having a plate-like or a needle-like shape tend to assume a preferred mode of orientation when mounted in the sample holder. If the degree of the preferred orientation is not high, a rather accurate value of $X$ can be obtained by averaging the data that follow from diffraction lines which are differently affected, by application of the plot of $I_{X d+a} / I_{Y d}$ as a function of $\left(I_{X} / I_{Y}\right)$ (26).

In case the preferred orientation of grains/crystallites is not present, the fractions of the phases can be found by comparison of the measured intensities of diffraction lines and the intensities of the same diffraction lines calculated on the basis of the crystal structure of the phases in question. For instance, the ratio of the molar fractions of rutile and anatase, $\mathrm{TiO}_{2}$, is given by

$$
R / A=1.25\left(I_{110 R} / I_{101 A}\right),
$$

where $I_{110 R}$ and $I_{10 I A}$ are the measured intensities of diffraction lines 110 and 101 of rutile and anatase, resp. [10].

The doping method (iii) is, in principle, based on the non-overlapping diffraction lines. If a phase, say $X$, exhibits several partially overlapped diffraction lines in a narrow angular interval, all these lines may be considered as a single diffraction line, if diffraction lines of other phases are not present in that interval. The problem of overlapping of diffraction lines can be overcome by means of the individual profile fitting method which enables derivation of the profiles of particular diffraction lines [11]. It has been suggested to combine the doping method (iii) and the individual profile fitting method, thus performing the quantitative phase analysis without the reference to structural models of particular phases [12].

The fractions of particular phases present in the studied system can be derived using the Rietveld method. That method is the so-called full pattern analysis technique. Models of the crystal structures of the phases present in the system, together with instrumental and background information, are used to generate the theoretical diffraction pattern that can be compared to the observed pattern. The least squares procedure is then used to minimize the difference between the calculated diffraction pattern and the observed diffraction pattern by adjusting model parameters. That procedure may result in determination of the fractions and microstructural parameters of the phases present in the system and in refinement of their crystal structures [13].

\section{REFERENCES}

[1] L. Alexander, H. P. Klug, X-ray diffraction analysis of crystalline dusts, Anal. Chem. 20, 886-889 (1948).

[2] H. P. Klug, L. E. Alexander, X-ray Diffraction Procedures, Chapter 7, New York, John Wiley, 1974.

[3] F. H. Chung, Quantitative interpretation of X-ray diffraction patterns of mixtures. I. Matrix-flushing method for quantitative multicomponent analysis; II. Adiabatic principle of X-ray diffraction analysis of mixtures , $J$. Appl. Cryst. 7, 519-525, 526- 531 (1974).

[4] F. H. Chung, Quantitative interpretation of X-ray diffraction patterns of mixtures. III. Simultaneous determination of a set of reference intensities, J. Appl. Cryst. 8, 17-19 (1975).

[5] L. E. Copeland, R. H. Bragg, Quantitative X-ray diffraction analysis, Anal. Chem. 30, 196-201 (1958).

[6] A. Bezjak, I. Jelenić, The application of the doping method in quantitative X-ray diffraction analysis, Croat. Chem. Acta 43, 193-198 (1971).

[7] S. Popović, B. Gržeta-Plenković, The doping method in quantitative X-ray diffraction phase analysis, J. Appl. Cryst. 12, 205-208 (1979).

[8] S. Popović, B. Gržeta-Plenković, T. Balić-Žunić, The doping method in quantitative $\mathrm{X}$-ray diffraction phase analysis. Addendum, J. Appl. Cryst. 16, 505-507 (1983).

[9] S. Popović, B. Gržeta-Plenković, Dilution and addition methods in quantitative X-ray diffraction phase analysis; in: Advanced Methods in X-ray and Neutron Structure Analysis in Materials Science, Editor J. Hašek, New York, Plenum Press, 1989, pp. 29-41.

[10] A. Gajović, K. Furić, N. Tomašić, S. Popović, Ž. Skoko, S. Musić, Mechanochemical preparation of nanocrystalline $\mathrm{TiO}_{2}$ powders and their behavior at high temperatures, Journal of Alloys and Compounds 398, 188-199 (2005).

[11] H. Toraya, Whole-powder-pattern fitting without reference to a structural model: application to X-ray powder diffraction data, J. Appl. Cryst. 19, 440-447 (1986).

[12] B. Gržeta, S. Popović, H. Toraya, DOP-FIT method for quantitative analysis of multicomponent powders, Materials Science Forum, 228-231, 49-54 (1996).

[13] R. A. Young, The Rietveld Method, Oxford, Oxford University Press, 1993. 